\title{
R Factors from Proteus morganii
}

\author{
By R. W. HEDGES AND NAOMI DATTA \\ Department of Bacteriology, Royal Postgraduate Medical School, \\ Hammersmith Hospital, London WI 2 OHS \\ J. N. COETZEE \\ Department of Microbiology, University of Pretoria, \\ Republic of South Africa \\ AND SHEENA DENNISON \\ Department of Genetics, University of Leeds, Leeds, LS2 $9 J T$
}

(Received 25 September 1972; revised 26 March 1973)

\begin{abstract}
SUMMAR Y
Twenty-eight $\mathrm{R}$ factors transmissible to Escherichia coli $\mathrm{KI} 2$ were derived from 178 naturally occurring strains of Proteus morganii and evidence was found of non-transmissible resistance plasmids in some strains. Nine plasmids were assigned to group $\mathrm{N}$; one $P$. morganii strain carried two $\mathrm{N}$ plasmids which were incompatible in reference strains of $E$. coli or $P$. morganii. Six $f^{+} \mathrm{R}$ factors of group FII were found. One was unique among F-like plasmids in conferring hspII restriction. Entry exclusion by these $\mathrm{R}$ factors had a specificity distinct from that of FII plasmids previously described. Three $\mathrm{R}$ factors of compatibility group FI were the first recognized plasmids of this group with repressed pilus synthesis. Two $\mathrm{fi}^{+} \mathrm{R}$ factors incompatible with $\mathrm{R} 6 \mathrm{~K}$ (and with this plasmid constituting group X) were identified, as were one plasmid of group $P$ and an $R$ factor compatible with plasmids of all groups so far described and therefore assigned to a new group (M). Similarities and differences between the $\mathrm{R}$ factor sets of $P$. morganii and $P$. rettgeri are discussed.
\end{abstract}

\section{INTRODUCTION}

The relationship of Proteus morganii to other Proteus species is uncertain. Ewing (1958) suggested that $P$. morganii, $P$. rettgeri and Providence should be united as a genus distinct from $P$. mirabilis and $P$. vulgaris which are closely related in biochemical properties (Smit \& Coetzee, I967) and in DNA homology (Brenner \& Falkow, 197I). Smit \& Coetzee ( I967) suggested that $P$. morganii should be raised to generic status as Morganella. Proteus morganii differs from the other members of the Proteus tribe in that the GC $\%$ of its DNA is > 50 whereas the GC\% for other members of the tribe is about 40 (Hill, I966). Despite this and other differences, most bacteriologists consider the Proteus tribe to be a natural group (Coetzee, I972). We have been sampling the sets of plasmids from taxa within the Proteus tribe to find out whether there are significant differences or relationships. Among $P$. rettgeri $\mathrm{R}$ factors (Coetzee, Datta \& Hedges, 1972), N plasmids (Datta \& Hedges, I97I) were the most abundant. Plasmids of groups $J$ and $T$ (Coetzee et al. 1972) and one of group W (Hedges \& Datta, I97I) were also observed. This R factor set is quite distinct from those of other groups of bacteria. For example, in Shigella flexneri a large majority of 
$\mathrm{R}$ factors are $f^{+}$, probably of group FII (Watson, I967; Yoshikawa, Nagashima \& Matsushima, I97I), whilst R factors from Salmonella are predominantly $f_{i}$ - (Meynell, Meynell \& Datta, I968), some I-like, some of the $\mathrm{N}$ group and some, conferring streptomycin and sulphonamide resistances, not yet assigned to any compatibility group (Lawn, Meynell, Meynell \& Datta, I967).

The selective pressures operating to establish and maintain plasmid differences between the taxa are largely unknown but some clues are available. For example many $f^{+} \mathbf{R}$ factors are unstable in Salmonella typhimurium (Watanabe \& Ogata, 1970) and in Proteus mirabilis (e.g. Kopecko \& Punch, I97I); I-like plasmids are unstable in Shigella (Yoshikawa et al. I97I). Failure of certain types of R factors to establish themselves in bacteria of particular species seems likely to influence distributions of various classes. For example I-like $\mathbf{R}$ factors fail to transfer to the Proteus tribe (Datta \& Hedges, 1972a) and hence we do not expect to find any I-like plasmids in this group. Even more severe is the restriction of transfer of plasmids to Pseudomonas aeruginosa. So far as is known, only plasmids of groups P (Datta et al. 197I) and C (Datta \& Hedges, 1972 b) can be transferred into $P$. aeruginosa, and plasmids of these two classes constitute the $\mathrm{R}$ factor set of this species.

\section{METHODS}

Proteus morganii. Wild-type $P$. morganii strains (167) were isolated in South Africa in I966-7 under the same conditions as those for the $P$. rettgeri collection (Coetzee et al. I972). Eleven wild-type $P$. morganii strains (which we designated M20I-2II) were isolated in New Haven (U.S.A.) by Dr A. von Graevenitz in 1972. Proteus morganii 2815 is an Rlaboratory strain (Coetzee, 1972).

Escherichia coli $\mathrm{KI} 2$ strains: $\mathrm{J}_{53} \mathrm{~F}^{-}$lac ${ }^{+}$, met, pro (Clowes \& Hayes, I968); J53-I, a nalidixic acid-resistant mutant of $\mathrm{J} 53 ; \mathrm{J} 62 \mathrm{~F}^{-}$lac, pro, his, $\operatorname{trp}$ (Clowes \& Hayes, 1968); $\mathrm{J62-I}$, a nalidixic acid-resistant mutant of J62; HfrC, Hfr met (Clowes \& Hayes, I968).

Salmonella typhimurium LT2 strain M329 trp.

Plasmids. Standard plasmids are listed in Table I, R factors derived from the Proteus morganii strains in Table 3 .

Phages. $\lambda$ vir (Jacob \& Wollman, I954). MS2 (Davis, Strauss \& Sinsheimer, 1961).

Media. Nutrient broth was Oxoid no. 2 (CM67); nutrient agar was the same solidified with $\mathrm{I} \cdot 2 \%$ New Zealand agar; for sensitivity tests, $4 \%(\mathrm{v} / \mathrm{v})$ lysed horse blood was incorporated in nutrient agar; MacConkey agar was Oxoid $\mathrm{CM}_{7} \mathrm{~b}$. Minimal salts agar was as described by Clowes \& Hayes (1968).

Detection of antibiotic resistance. In both wild strains and strains of Escherichia coli $\mathrm{KI} 2$, the resistance spectrum to eight drugs was scored using Oxoid 'multidisks' (code no. $30-44 \mathrm{~K}$ ) and individual discs placed on plates of lysed blood agar.

Transfer and compatibility of plasmids, $f i$ determination, isolation of segregants were as described by Coetzee et al (1972).

Bacteriophage increase. Multiplication of phage $\mathrm{MS}_{2}$ in $\mathrm{R}^{+}$cultures (for evidence of the presence of F pili) was measured as described by Datta et al (I966).

Restriction and modification of $\lambda v i r$. The $h s p \mathrm{II}$ restriction by $\mathrm{R}$ factors was determined as described by Hedges (1972). 
Table $\mathrm{I}$. 'Standard' plasmids of various compatibility groups

\begin{tabular}{|c|c|c|c|}
\hline Plasmid & Characteristics* & $\begin{array}{l}\text { Compatibility } \\
\text { group }\end{array}$ & Reference \\
\hline Flac & $\mathrm{Lac}^{-}$ & FI & Jacob \& Adelberg (1959) \\
\hline $\mathrm{R}_{386}$ & $\mathbf{T}$ & FI & Dennison (1972) \\
\hline $\mathrm{Rl} d r d \mathrm{I} 6$ & $\mathbf{K}$ & FII & Meynell \& Datta (1967) \\
\hline Rl-1 & $\mathrm{ASCSu}$ & FII & Coetzee et al. (1972) \\
\hline ColB-K98 & $\mathrm{Col} \mathrm{B}^{+}$ & FIII & Frydman \& Meyneil (1969) \\
\hline $\mathrm{R}_{124}$ & $\mathrm{~T}$ & FIV & Hedges \& Datta (1972) \\
\hline RI44 & TK ColI ${ }^{+}$ & I & Lawn, Meynell, Meynell \& Datta (1967) \\
\hline $\mathrm{R} 64$ & ST & I & Lawn, Meynell, Meynell \& Datta (1967) \\
\hline RI 5 & SSu, hspII & $\mathrm{N}$ & Datta \& Hedges (1971) \\
\hline R45 & ATSu & $\mathbf{N}$ & Hedges (1972) \\
\hline R269N-I & ASTK, hspII & $\mathbf{N}$ & Hedges (1972) \\
\hline $\mathrm{R} 245$ & $\mathbf{T}$ & $\mathbf{N}$ & Hedges ( I972) \\
\hline $\mathrm{RP}_{4}$ & ATK & $\mathbf{P}$ & Datta, Hedges, Shaw, Sykes \& Richmond (197I) \\
\hline R75 I & $\mathrm{Tp}$ & $\mathbf{P}$ & Datta \& Jobanputra (unpublished) \\
\hline S-a & SCKSu & W & Hedges \& Datta (197I) \\
\hline R388 & SuTp & W & Datta \& Hedges (I972c) \\
\hline R7K & AS & W & Coetzee et al. (1972) \\
\hline $\mathrm{R} 57 \mathrm{~b}$ & ACSuGk & $\mathrm{C}$ & Witchitz \& Chabbert (1972), Datta \& Hedges (I972b) \\
\hline R39I & $\mathrm{K}$ & $\mathbf{J}$ & Coetzee et al. (1972) \\
\hline RAI & TSu & A & Hedges \& Datta (I97I) \\
\hline R300 & SSu & Undesignated & Lawn et al. (1967) \\
\hline R387 & SC & Undesignated & Hedges \& Datta (I97I) \\
\hline R6K & AS & $\mathrm{X}$ & Kontomichalou, Mitani \& Clowes (1970) \\
\hline $\mathrm{R}_{483}$ & STp & B & Hedges, Datta \& Fleming (1972) \\
\hline R40I & AS & $\mathbf{T}$ & Coetzee et al. (1972) \\
\hline Rtsl & $\mathrm{K}$ & $\mathbf{T}$ & Coetzee et al. (1972) \\
\hline
\end{tabular}

* Abbreviations for resistance markers: A, ampicillin; S, streptomycin; T, tetracycline; $\mathrm{C}$, chloramphenicol; K, kanamycin; Gk, gentamicin (and low-level kanamycin); Su, sulphonamides; Tp, trimethoprim.

\section{RESULTS AND DISCUSSION}

Resistance phenotypes of the Proteus morganii strains. Of the 167 strains from South Africa, all were resistant to polymixin, 80 to tetracycline, 69 to streptomycin, 66 to sulphonamides, 63 to chloramphenicol, 5 I to ampicillin, I I to kanamycin and one to nitrofurantoin (Table 2).

Transfer of drug resistance to Escherichia coli $\mathrm{KI} 2$ and properties of the exconjugants. Transfer of every resistance determinant except polymixin and nitrofurantoin from each Proteus morganii strain to Escherichia coli $\mathrm{J62- \textrm {I }}$ was attempted. Those cases in which $\mathrm{R}$ transfer was observed are recorded in Table 3. Nine of the $\mathrm{R}$ factors conferred upon $\mathrm{J62-I}$ restriction specificity $h s p I I$. Eight $\mathrm{R}$ factors, when carried by $\mathrm{HfrC}$, prevented visible lysis by phage MS2, i.e. these were $f^{+}$(Watanabe, Nishida, Ogata, Arai \& Sato, 1964). Three other plasmids, R453, R455 and R456, gave ambiguous answers in the $f i$ test, unless the $\mathrm{R}^{+} \mathrm{HfrC}$ strains were tested in the presence of an antibiotic selecting against $\mathrm{R}^{-}$ segregants, when their $f^{+}$character was evident.

F-pilus production by $f^{+} R$ factors. Strains carrying $f^{+} \mathrm{R}$ factors of three compatibility groups (FI, FII and X) were tested for F-like pili. Strains carrying R444 or R455 supported the multiplication of phage MS2 with an efficiency comparable with that of strains carrying wild-type (repressed for pilus synthesis) RI. R444 and R455, therefore, determine F-like pili. R $485^{+}$Escherichia coli did not support multiplication of MS2. 
Table 2. Resistance spectra of the Proteus morganii strains

$\begin{array}{lrlc}\text { Resistance } & \text { Number } & \text { Resistance } & \text { Number } \\ \text { None } & 67 & \text { ATC } & 2 \\ \text { C } & 2 & \text { ASC } & 5 \\ \text { Su } & 2 & \text { STSu } & 8 \\ \text { A } & 3 & \text { ATCSu } & \text { I } \\ \text { T } & 12 & \text { ASTC } & 1 \\ \text { AT } & \text { I } & \text { ASTSu } & 3 \\ \text { SC } & 2 & \text { STCSu } & 8 \\ \text { TSu } & 2 & \text { STCSuFz } & \text { I } \\ \text { TC } & 6 & \text { ASTCSu } & 24 \\ \text { SSu } & 6 & \text { ASTCSuK } & \text { II }\end{array}$

* Abbreviations as in Table $\mathbf{I}$; in addition Fz indicates resistance to furazolidone.

Table 3. $R$ factors from Proteus morganii

$\begin{array}{llll}\text { Strain } & \text { Characters transferred* to Escherichia coli KI2 } & \text { Designation } & \text { Compatibility } \\ \text { group }\end{array}$

* Abbreviations as for Table I. In addition Sp indicates resistance to spectinomycin.

\section{Group FI plasmids}

$\mathrm{R} 453, \mathrm{R} 455$ and $\mathrm{R} 456$, which all conferred the same resistance pattern, gave ambiguous results in the $f$ test because they were unstable in HfrC. All three were incompatible with Flac. Thus these R factors belong to group FI. Various segregants of R455 were isolated and their compatibility properties tested. R455-2 (a tetracycline-sensitive segregant) was incompatible with $\mathrm{R}_{3} 86$, thus confirming $\mathrm{R} 455$ as an FI plasmid. Appropriate segregants were compatible with standard plasmids of all other groups. 
Table 4. Compatibility and exclusion properties of FII plasmids from Proteus morganii

$\begin{array}{clccc}\text { Donor } & \text { Recipient } & \begin{array}{c}\text { Antibiotic } \\ \text { resistance } \\ \text { selected }\end{array} & \begin{array}{c}\text { Efficiency } \\ \text { of transfer }\end{array} & \begin{array}{c}\text { Character of } \\ \text { recombinant }\end{array} \\ \mathrm{J}_{53}\left(\mathrm{Rl} d r d_{\mathrm{I}} 6\right) & \mathrm{J} 62-\mathrm{I} & \mathrm{K} & 2 \times 10^{-1} & - \\ & \mathrm{J} 62-\mathrm{I}(\mathrm{R} 444) & \mathrm{K} & \mathrm{I} \times \mathrm{IO}^{-1} & 10 \text { of } \mathrm{Io} \mathrm{K}^{\mathrm{R}} \mathrm{C}^{\mathrm{s}} \\ \mathrm{J} 62-\mathrm{I}(\mathrm{R} 444) & \mathrm{J} 53 & \mathrm{C} & 4 \times 10^{-2} & - \\ & \mathrm{J} 53(\mathrm{Rl} d r d \mathrm{I} 6) & \mathrm{C} & 2 \times \mathrm{IO}^{-2} & 10 \text { of } \mathrm{I0} \mathrm{C}^{\mathrm{R}} \mathrm{K}^{\mathrm{s}} \\ \mathrm{J} 62-\mathrm{I}(\mathrm{R} 444) & \mathrm{J} 53(\mathrm{R} 444-5) & \mathrm{C} & 3 \times \mathrm{IO}^{-3} & -\end{array}$

* The superscripts $\mathbf{R}, \mathbf{S}$ denote resistance and sensitivity respectively, to the drugs concerned. Other abbreviations as in Table $\mathrm{I}$.

The presence of $\mathrm{R} 453, \mathrm{R} 455$ or R456 in a strain of $\mathrm{J} 53$ reduced the plaque titre of $\lambda$ vir; the level of reduction was very variable but usually approached $10^{-4}$. The phage was not modified, but inhibited by an unknown mechanism.

These R factors were unlike the FI plasmids so far described (Dennison, I972) in that their pilus production was repressed.

\section{Group FII plasmids}

Most, but not all, $f^{+} \mathrm{R}$ factors belong to the FII compatibility group (Watanabe et al. 1964; Lawn et al. 1967; Dennison, 1972; Hedges \& Datta, 1972). Therefore, the five $f^{+} \mathrm{R}$ factors R444, R445, R452, R457 and R458 were tested for compatibility with R Idrdi6. All these $\mathrm{R}$ factors were incompatible with R $\mathrm{I} d r d \mathrm{I} 6$ but were unusual among FII plasmids in not significantly excluding this $\mathrm{R}$ factor (Watanabe et al. I964; Meynell \& Datta, I969).

$\mathrm{R} 444$, taken as the representative of this apparently homogeneous group, was excluded by R IdrdI 6 very slightly, if at all. To test whether R 444 was totally incapable of exclusion or had a different exclusion specificity from R $\mathrm{I} d r d \mathrm{I} 6$ (and hence from that of all FII plasmids previously tested) segregants having lost particular resistance markers were sought. None was found among about $\mathrm{IO}^{4}$ clones of $\mathrm{J} 62-\mathrm{I}$ ( $\left.\mathrm{R} 444\right)$ but, as is common with $\mathrm{fi}^{+} \mathrm{R}$ factors, segregants were found in an $\mathrm{R}_{444^{+}}$strain of Salmonella typhimurium LT2 (see Watanabe \& Ogata, 1970). No $\mathrm{C}^{\mathrm{R}} \mathrm{S}^{\mathrm{s}}$ or $\mathrm{C}^{\mathrm{s}} \mathrm{S}^{\mathrm{R}}$ segregants were found but $10 \%$ of clones were $\mathrm{C}^{\mathrm{S}} \mathrm{S}^{*}$. Of 57 such clones tested $5 \mathrm{I}$ were $\mathrm{A}^{\mathrm{R}} \mathrm{T}^{\mathrm{R}}$, two were resistant to ampicillin only and four had lost all resistance markers. The segregants conferring resistance to ampicillin only were non-transmissible but the $\mathrm{A}^{\mathrm{R}} \mathrm{T}^{\mathrm{R}}$ segregants were transferred to Escherichia coli $\mathrm{J} 53$. Two such segregants, R444-4 and R444-5, excluded wild-type R444 (Table 4).

Typical $f^{+}$, FII $\mathrm{R}$ factors exclude one another very efficiently (Watanabe et al. I964; Meynell et al. 1968). Thus the FII plasmids of Proteus morganii are not typical members of their group but appear to have undergone a significant evolutionary divergence from the homologous plasmids of Escherichia coli, Salmonella and Shigella. They might either be incapable of effecting or suffering exclusion or they might confer and be susceptible to a new specificity of exclusion distinct from that of $\mathrm{R} I d r d \mathrm{I} 6$. The exclusion of wild-type $\mathrm{R} 444$ by its segregants, R444-4 and R444-5 confirmed the latter model (Table 4 ). This is the first reported example of two $\mathrm{R}$ factors of a single compatibility group showing distinct exclusion specificities.

R444 resembled several other $f^{+} \mathbf{R}$ factors in being unstable in Salmonella typhimurium LT2. Watanabe \& Ogata (I970) showed that the recA gene of LT2 is necessary for this instability. Thus plasmid deletions are mediated by the bacterial recombination system in 
contrast to deletions of the Escherichia coli chromosome whose occurrence is independent of the recombination machinery (Franklin, 1967; Inselburg, 1967; Hedges, 1969; Anderson, I970; Spudich, Horn \& Yanofsky, I970). The commonest type of segregant produced from R444 in S. typhimurium conferred resistance to ampicillin and tetracycline only. We failed to find any segregants sensitive to chloramphenicol but resistant to streptomycin, or vice versa, in about $10^{4}$ clones replica-plated. Thus, apparently R444 carried sites highly susceptible to attack by the $S$. typhimurium recombination system (though not that of $E$. coli) located so as to permit dissociation of the genes conferring resistance to chloramphenicol, streptomycin and sulphonamides from those responsible for the other resistances, plasmid replication and transmissibility.

R459 appeared to be both $f^{+}$and $h s p \mathrm{II}^{+}$. It was, thus, necessary to exclude the possibility that R459+ strains actually carried two plasmids, one of group FII and one of group N. Transfer of chloramphenicol or tetracycline resistance from Proteus morganii MII to Escherichia coli KI 2 usually involved transfer of all genetic characters including $h s p \mathrm{II}^{+}$ and $f^{+}$markers but about $10 \%$ of exconjugants were non-restricting and lacked kanamycin resistance. The plasmids in these clones were $f^{+}$and incompatible with RIdrdI 6 .

All kanamycin-resistant exconjugants were resistant to so many agents (A, S, Sp, T, C, $\mathrm{K}$, Su and $\mathrm{Hg}^{2+}$ ions) that their compatibility with standard $\mathrm{R}$ factors could not be tested. Therefore clones of KI 2 (R459) carrying segregants lacking one or more resistance markers were isolated. From the patterns of markers lost we were able to construct a genetic map (Fig. I).

One of the segregants, R459-13, lacked resistance to ampicillin, streptomycin and kanamycin but retained $h s p \mathrm{II}$ specificity. Matings in which R IdrdI 6 (group FII) or R45 (group $\mathrm{N}$ ) were transferred to this strain showed that the $h s p$ II restriction was carried by a plasmid with FII compatibility properties. Other crosses demonstrated that all the antibiotic resistance markers associated with R459 were carried on the FII plasmid.

R459 is the first exception to the generalization (Hedges, 1972) that all plasmids conferring $h s p \mathrm{II}$ specificity are members of the $\mathrm{N}$ compatibility group. Perhaps this plasmid has been derived by recombination between an $f^{+} \mathrm{R}$ factor (similar to $\mathrm{R} 444$, etc) and an $\mathrm{N}$ plasmid. We have observed one example of recombination between an $\mathbf{N}$ and an $f^{+} \mathbf{R}$ factor (Hedges, I972) and suggested that chloramphenicol resistance of $\mathrm{N}$ plasmids such as $\mathrm{R} 390$ (Coetzee et al. 1972) may have originated from F-like $\mathrm{R}$ factors. W. V. Shaw (personal communication) has found that the chloramphenicol transacetylase produced by $\mathrm{R} 390$ is indistinguishable electrophoretically from that produced by $f^{+} \mathrm{R}$ factors.

\section{Group $N$ plasmids}

Since all previously described plasmids conferring $h s p$ II specificity are members of the N compatibility group (Datta \& Hedges, I97I ; Hedges, 1972) the eight Proteus morganii $\mathrm{R}$ factors R446c, R447a, R448, R454, R46I, R462, R465 and R467 all conferring $h s p I I$, were tested for compatibility with $\mathrm{N}$ plasmids. All these $\mathrm{R}$ factors displaced and were displaced by known $\mathrm{N}$ plasmids.

R447b, conferring resistance to ampicillin and kanamycin, excluded and was excluded by $\mathrm{RI} 5$ and the two plasmids were incompatible. R447b was therefore an N plasmid (Table 5).

R447a, derived from the same culture, Proteus morganii mi6, also belonged to compatibility group N (see above). R447a and $\mathrm{R}_{477 \mathrm{~b}}$ were incompatible in both Escherichia coli KI 2 and $P$. morganii $28 \mathrm{I} 5$ (Table 5). With $P$. morganii MI 6 as donor and $E$. coli $\mathrm{KI} 2$ J53-I as recipient, chloramphenicol resistance was transferred with an efficiency greater 


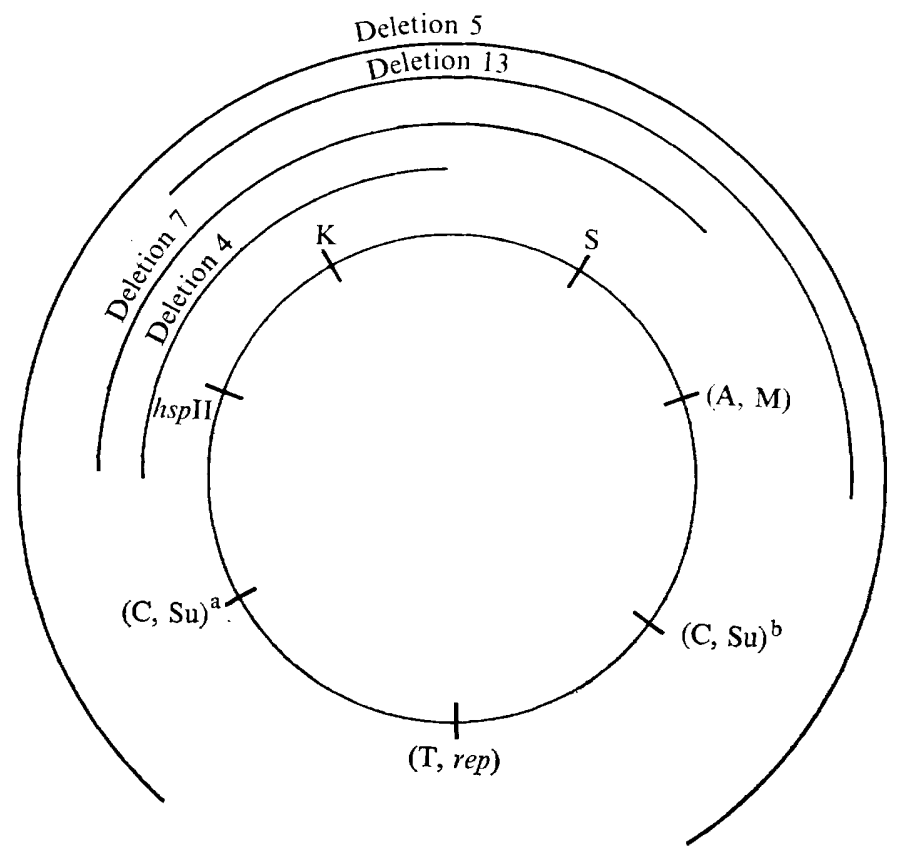

Fig. I. Deletion map of R459. A genetic map of R459 based on the properties of spontaneous segregants. It is assumed that all deletions arise by elimination of a single continuous segment (shown as arcs). Distances between genetic markers are arbitrary.

$\begin{array}{lllllllll}\text { Segregants } & \text { A } & \text { S } & \text { T } & \text { C } & \text { Su } & \text { K } & \text { M } & h s p I I \\ 4 & + & + & + & + & + & - & + & - \\ 5 & - & - & + & - & - & - & - & - \\ 7 & + & - & + & + & + & - & + & - \\ \text { I3 } & - & - & + & + & + & - & - & +\end{array}$

A, Amplicillin resistance; S, streptomycin resistance; T, tetracycline resistance; C, chloramphenicol resistance; $\mathrm{Su}$, sulphonamide resistance; $\mathrm{K}$, kanamycin resistance; $\mathrm{M}$, mercury resistance; rep, replication functions; $h s p I I$, restriction genes; $(\mathrm{C} \mathrm{Su})^{\mathrm{a}}$ and $(\mathrm{C} \mathrm{Su})^{\mathrm{b}}$, the two possible locations for these genes.

Table 5. Compatibility properties of $R 447 a$ and $R 477 b$

Donor

J53 (269N-I)

J62-I (R447b)

J53 (RI5)

J53 (R447b)

J62-1 (R447a)

J62-1 (R447a)
Recipient

J62-I

J62-I (R447a)

$\mathrm{J} 53$

J53 (RI5)

J62-I

J62-I (R447b)

J62-I

J62-I (R447a)

J53

J53 (R447b)

Proteus morganii

2815

P. morganii

2815 (R447b)

\section{Antibiotic}

resistance selected

K

$\mathrm{K}$

$\mathrm{K}$

$\mathbf{S}$

S

K

K

C

S

S
Efficiency of transfer

$$
\begin{aligned}
& 1 \times 10^{-4} \\
& 9 \times 10^{-6} \\
& 1 \times 10^{-3} \\
& 2 \times 10^{-5} \\
& 2 \times 10^{-3} \\
& 1 \times 10^{-4} \\
& 3 \times 10^{-3} \\
& 4 \times 10^{-5} \\
& 6 \times 10^{-4} \\
& 1 \times 10^{-4} \\
& I \times 10^{-5} \\
& I \times 10^{-6}
\end{aligned}
$$

10 of $10 \mathrm{~K}^{\mathrm{S}} \mathrm{C}^{\mathrm{R}}$

Abbreviations as in Table 4. 
than $10^{-3}$, kanamycin resistance with an efficiency of about $10^{-5} /$ donor cell, but no $E$. coli exconjugant simultaneously resistant to both antibiotics was observed: the efficiency of co-transfer of the two resistance genes was $<10^{-7}$. In $P$. morganii MI6, either the two plasmids existed as a single entity or MI6 was unusual in permitting stable coexistence of the two incompatible plasmids. Since attempts to transfer genetic markers from both plasmids to cells of $E$. coli KI 2 consistently failed one must either reject the notion that R447a and $\mathrm{R} 447 \mathrm{~b}$ exist as a single structure or postulate that this plasmid is obligatorily broken during transfer. A mutant of $E$. coli KI 2 in which two incompatible F plasmids can coexist stably has been described (Palchoudhury \& Iyer, I97I). It may be that P. morganii MI 6 is a naturally occurring strain with analogous properties.

$\mathrm{R} 447 \mathrm{~b}$ is the first naturally occurring $\mathrm{N}$ plasmid so far described which confers kanamycin resistance. An $\mathrm{N}$ plasmid conferring resistance to kanamycin, R269N-I, has however been observed in the laboratory, produced by recombination between an $\mathrm{N}$ plasmid and an $f^{+} \mathbf{R}$ factor (Hedges, 1972).

\section{Group $P$ plasmid}

$\mathrm{R} 446 \mathrm{a}$, conferring resistance to ampicillin, was incompatible with $\mathrm{R} 75 \mathrm{I}$, which confers resistance to trimethoprim and belongs to compatibility group $P$ (N. Datta and $R$. S. Jobanputra, unpublished). R446a could not be tested for compatability with the prototype P plasmid, RP4 (Datta et al. $197 \mathrm{I}$ ), since no segregant of $\mathrm{RP}_{4}$, lacking ampicillin resistance genes, was available. R446a was compatible with plasmids of all other defined groups.

\section{Group X plasmids}

$\mathrm{R} 485$ and $\mathrm{R} 487$, apparently identical, conferred resistance to sulphonamides only. They were $f^{+}$and even reduced the transfer rate of R386 (a naturally occurring FI plasmid derepressed for $F$ pilus synthesis and not susceptible to fertility inhibition by F-like R factors). Thus their $f$ character was different from that of normal F-like $\mathrm{R}$ factors. They resemble two non-F-like but $f^{+} \mathrm{R}$ factors JR66a (Datta \& Hedges, I973) and R62 (Meynell, I973). Perhaps some non-F-like plasmids have evolved independently a mechanism for reducing the F-piliation of cells carrying F-like plasmids, operating at a different level from the repression mechanism of F-like plasmids. The prevalence of phages which adsorb to F pili (Loeb, I960; Marvin \& Hohn, 1969; Miyake, Shiba, Sakurai \& Watanabe, 1969) and the occurrence of plasmids derepressed for F-pilus synthesis (F, Folac, ColV and R386) (and of physiological derepression of plasmids whose $\mathrm{F}$ pilus production is genetically repressed) makes it an advantage for a non-F-like plasmid to be able to repress F-pilus synthesis by a co-habiting plasmid, so that the $f^{+}$phenotype is, in effect, a resistance determinant.

R485 and R487 were compatible with all tested plasmids except R6K, the only plasmid previously allocated to group X. R6K exists in Escherichia coli $\mathrm{KI} 2$ in multiple copies (Kontomichalou et al. 1970). Since it is possible to eliminate R6K by introduction of an incompatible plasmid, incompatibility cannot be interpreted as operating through the mechanism which imposes stringent control on plasmid replication.

\section{Group $M$ plasmid}

R446b, conferring resistance to tetracycline and streptomycin, was compatible with plasmids of all $f^{-}$groups (RI44, R45, R388, Rtsl, RP4, R57b, R39I, RAI, R300, R483, R6K and $\mathrm{R}_{387}$ ). It was therefore the prototype of a new compatibility group which we designate $M$. 


\section{Streptomycin-sulphonamide resistance factors}

R450, R45 I, R466 and R496 conferred resistance to streptomycin (but not spectinomycin) and sulphonamides. R466, chosen as apparently typical, was shown to be compatible with all the R factors tested with $\mathrm{R}_{4} 60$ (see below). R466 resembled R300 in all tested exclusion, compatability, and drug-resistance characteristics except that it neither excluded R483 nor was excluded by it (see Hedges, Datta \& Fleming, 1972).

R460 conferred resistance to spectinomycin, as well as streptomycin and sulphonamides. Thus, presumably, it determines streptomycin/spectinomycin adenylate synthetase (Davies, Brzezinska \& Benveniste, I97I). It was compatible with RIdrdI6 and with members of all $f^{-}$groups tested (RI44, R245, RP4, R388, R40I, R57b, R39I, RAI, R6K, R387, R483 and $R 446 b)$. It could not be tested with $R 300$.

Numerous streptomycin-sulphonamide $\mathrm{R}$ factors have been reported from other genera (e.g. Lawn et al. 1967). None of these is incompatible with any testable plasmid and it is not known whether they constitute a single group. To obtain genetic markers that could be tested we have looked for segregants of R300 and R466 lacking either streptomycin or sulphonamide resistance and have attempted to translocate the kanamycin resistance of Rtsl on to R300 (see Yokata, Kanamaru, Mori \& Akiba, 1969) but neither procedure was successful, so we have been unable to determine the compatibilities of these plasmids.

\section{Strains of Proteus morganii not transferring resistances to Escherichia coli}

Two strains M52 and M94, both resistant to A, S, T, C, Su and K, were never observed to transfer any of these resistances to Escherichia coli. Segregants lacking chloramphenicol resistance were sought. Of sixteen such segregants isolated from M52, thirteen retained all other resistances whilst three retained resistance only to $\mathrm{A}, \mathrm{T}$ and $\mathrm{K}$. Of four segregants from M94, three had lost only $\mathrm{C}$ resistance whilst one retained resistance only to $\mathrm{A}, \mathrm{T}$ and $\mathrm{K}$. The coincident loss of several resistances implies that the genes responsible were organized into a unit, presumably a non-transmissible plasmid.

\section{CONCLUSIONS}

The resistance patterns of the Proteus morganii strains, shown in Table 2, have several features of interest. Whereas $P$. mirabilis and $P$. rettgeri are normally resistant to tetracycline, $P$. morganii is naturally sensitive to this drug (Turck, 1967; Tomaschoff, 1969; von Graevenitz \& Nourbakhsh, 1972).

Many strains showed resistance to A, S, T, C and Su and a high proportion of the transmissible R factors from Proteus morganii (I3 of 28) (Table 2) conferred this resistance pattern. A similarly high proportion of $\mathrm{R}$ factors from $P$. rettgeri conferred the same resistance pattern (Coetzee et al. 1972) but all of these belonged to the $\mathrm{N}$ compatibility group whereas the $\mathrm{A}, \mathrm{S}, \mathrm{T}, \mathrm{C}, \mathrm{Su} \mathrm{R}$ factors from $P$. morganii include plasmids of three different compatibility groups, N, FI and FII. So far as we know, plasmids of the latter groups are the first F-like plasmids detected in naturally occurring Proteus strains. As was the case with $\mathrm{R}$ factors from $P$. rettgeri, none of those from $P$. morganii belonged to the $\mathrm{I}$ compatibility group. It now seems that plasmids of this compatibility group are almost exclusive to Salmonella (Datta \& Hedges, I97I; Yoshikawa et al. I97I). The commonest $\mathrm{R}$ factors in both $P$. rettgeri and $P$. morganii were $\mathrm{N}$ plasmids. In both species the most frequent $\mathrm{N}$ plasmids conferred $\mathrm{A}, \mathrm{S}, \mathrm{T}, \mathrm{C}$ and $\mathrm{Su}$ resistances and $h s p \mathrm{II}$ specificity. Chloramphenicol resistance has not been observed in $\mathrm{N}$ plasmids from any other genera. 
The set of $\mathrm{R}$ factors found in strains of Proteus morganii resembled that of $P$. rettgeri (Coetzee et al. 1972) in that $\mathrm{N}$ was the most common compatibility group and in the high proportion of plasmids conferring resistance to $\mathrm{A}, \mathrm{S}, \mathrm{T}, \mathrm{C}$ and $\mathrm{Su}$. It differed from the latter set in including a high proportion of $f_{i}^{+}$plasmids.

We are grateful to Dr A. von Graevenitz, Yale-New Haven Hospital, for strains of Proteus morganii. N. D., J. N. C. and S. D. are in receipt of grants from the Medical Research Council of Great Britain, the South African Medical Research Council and the Wellcome Foundation, respectively.

\section{REFERENCES}

ANDerson, C. W. (1970). Spontaneous deletion formation in several classes of Escherichia coli mutants deficient in recombination ability. Mutation Research 9, 155-165.

BRENNER, D. J. \& FALKow, S. (197I). Molecular relationships among members of the Enterobacteriaceae. Advances in Genetics $16,8 \mathrm{I}-118$.

Clowes, R. C. \& HAYES, W. (1968). Experiments in Microbial Genetics. Oxford and Edinburgh: Blackwell Scientific Publications.

Coetzee, J. N. (1972). Genetics of the Proteus group. Annual Review of Microbiology 26, 23-54.

Coetzee, J. N., Datta, N. \& Hedges, R. W. (1972). R factors from Proteus rettgeri. Journal of General Microbiology 72, 543-552.

Datta, N. \& Hedges, R. W. (I97I). Compatibility groups among $f^{-}$R factors. Nature, London 234, 222-223.

DatTA, N. \& Hedges, R. W. (1972a). Host ranges of R factors. Journal of General Microbiology 70, 453-460.

Datta, N. \& Hedges, R. W. (1972 b). R factors identified in Paris, some conferring gentamicin resistance, constitute a new compatibility group. Annales de l'Institut Pasteur I23, 849-852.

Datta, N. \& Hedges, R. W. (1972c). Trimethoprim resistance conferred by W plasmids in Enterobacteriaceae. Journal of General Microbiology 72, 349-355.

Datta, N. \& Hedges, R. W. (1973). An I-pilus determining R factor with anomalous compatibility properties, mobilizing a gentamicin-resistance plasmid. Journal of General Microbiology 77, I I-I 7.

Datta, N., Hedges, R. W., Shaw, E. J., Sykes, R. B. \& Richmond, M. H. (1971). Properties of an R factor from Pseudomonas aeruginosa. Journal of Bacteriology 108, I244-1249.

Datta, N., Lawn, A. M. \& Meynell, E. (1966). The relationship of F type pilation and F phage sensitivity to drug resistance transfer in $\mathrm{R}^{+} \mathrm{F}^{-}$Escherichia coli. Journal of General Microbiology 45, 365-376.

DAVIES, J., BRZEZINSKA, M. \& BeNVENISTE, R. (1971). R factors: biochemical mechanisms of resistance to aminoglycoside antibiotics. Annals of the New York Academy of Sciences 182, 226-233.

Davis, J. E., Strauss, J. H. \& Sinshermer, R. L. (I96I). Bacteriophage MS2 : another RNA phage. Science, New York 134, 1427.

Dennison, S. (1972). Naturally occurring R factor, derepressed for pilus synthesis, belonging to the same compatibility group as the sex factor F of Escherichia coli K-I 2. Journal of Bacteriology 109, 4I6-422.

Ewing, W. H. (1958). The nomenclature and taxonomy of the Proteus and Providence groups. International Bulletin of Bacteriological Nomenclature and Taxonomy 8, 17-22.

FrankLIN, N. C. (1967). Extraordinary recombinational events in Escherichia coli. Their independence of the $\mathrm{rec}^{+}$function. Genetics 55, 699-707.

Frydman, A. \& Meynell, E. (1969). Interactions between derepressed F-like R factors and wild type Colicin B factors: superinfection immunity and repressor susceptibility. Genetical Research 14, 31 5-332.

von Graevenitz, A. \& Nourbakhsh, M. (1972). Antimicrobial resistance of the genera Proteus, Providence and Serratia with special reference to multiple resistance patterns. Medical Microbiology \& Immunology 157, $142-148$.

HEDGES, R. W. (1969). Preliminary studies on the genetics of bacteriophages capable of generalized transduction. Ph.D Thesis, University of Leicester.

Hedges, R. W. (1972). Phenotypic characterization of $f^{-} \mathrm{R}$ factors determining the restriction and modification hsp II specificity. Molecular and General Genetics 115, 225-233.

HedGes, R. W. \& DATTA, N. (197I). $f^{-}$R factors giving chloramphenicol resistance. Nature, London 234, 220-22I. 
Hedges, R. W. \& DAtTA, N. (1972). Ri24, an $f^{+}$R factor of a new compatibility class. Journal of General Microbiology 7I, 403-405.

Hedges, R. W., Datta, N. \& Fleming, M. P. (1972). R factors conferring resistance to trimethoprim but not sulphonamides. Journal of General Microbiology 73, 573-575.

HrLl, L. R. (1966). An index to DNA base compositions of bacterial species. Journal of General Microbiology 44, 419-437.

INSELBURG, J. (1967). Formation of deletion mutations in recombination deficient mutants of Escherichia coli. Journal of Bacteriology 94, $1266-1267$.

JACOB, F. \& ADELBERG, E. A. (I959). Transfert de caractères génétiques par incorporation au facteur sexuel d'Escherichia coli. Comptes rendues hebdomadaires des séances de l'Académie des sciences 249, 189-193.

JaCOB, F. \& Wollman, E. L. (1954). Étude génétique d'un bactériophage tempéré d'Escherichia coli. I. Le système génétique du bactériophage lambda. Annales de l'Institut Pasteur 87, 653-675.

Kontomichalou, P., Mitani, M. \& Clowes, R. C. (1970). Circular R-factor molecules controlling penicillinase synthesis, replicating in Escherichia coli under relaxed or stringent control. Journal of Bacteriology 104, 34-44.

Kopecko, D. J. \& Punch, J. D. (I971). Regulation of R factor replication in Proteus mirabilis. Annals of the New York Academy of Sciences 182, 207-2 16.

Lawn, A. M., Meynell, E., Meynell, G. G. \& Datta, N. (1967). Sex pili and the classification of sex factors in the Enterobacteriacea. Nature, London 216, 343-346.

LoEB, T. (1960). Isolation of a bacteriophage for the $\mathrm{F}^{+}$and $\mathrm{Hfr}$ mating types of Escherichia coli KI 2. Science, New York, I3I, 932-933.

Marvin, D. A. \& Hohn, B. (I969). Filamentous bacterial viruses. Bacteriological Reviews 33, 172-209.

Meynell, E. (I973). Pseudo- $f^{+}$I-like sex factor, R62 (I), selective for increased pilus synthesis. Journal of Bacteriology $113,502-503$.

Meynell, E. \& DatTa, N. (1967). Mutant drug resistance factors of high transmissibility. Nature, London 214, $885-887$.

Meynell, E. \& Datta, N. (1969). Sex factor activity of drug resistance factors. In Bacterial Episomes and Plasmids, pp. 120-133. CIBA Symposium. Edited by G. E. W. Wolstenholme and M. O'Connor. London: J. \& A. Churchill.

Meynell, E., Meynell, G. G. \& Datta, N. (1968). Phylogenetic relationships of drug-resistance factors and other transmissible bacterial plasmids. Bacteriological Reviews 32, 55-83.

Miyake, T., Shiba, T., Sakurai, T. \& Watanabe, I. (I969). Isolation and properties of two new RNA phages SP and FI. Japanese Journal of Microbiology 13, 375-382.

Palchoudhury, S. R. \& Iyer, V. N. (1971). Compatibility between two $\mathrm{F}^{\prime}$ factors in Escherichia coli strain bearing a chromosomal mutation affecting DNA synthesis. Journal of Molecular Biology 57, 319-333.

SMit, J. A. \& CoetzeE, J. N. (I967). Serological specificities of phenylalanine deaminases of the ProteusProvidence group. Nature, London 214, I $238-1239$.

Spudich, J. A., Horn, V. \& YANOFSKY, C. (1970). On the production of deletions in the chromosome of Escherichia coli. Journal of Molecular Biology 53, 49-67.

Tomaschoff, E. (1969). Die Ökologie und Bedeutung der Proteusgruppe. Klinische Wochenschrift 47, $837-844$.

Turck, M. (1967). The problem of infections due to gram negative organisms. Antimicrobial Agents \& Chemotherapy, 265-273.

Watanabe, T., Nishida, H., Ogata, C., Arai, T. \& Sato, S. (i964). Episome mediated transfer of drug resistance in Enterobacteriaceae. VII. Two types of naturally occurring R factors. Journal of Bacteriology 88, 716-726.

Watanabe, T. \& OGata, Y. (1970). Genetic stability of various resistance factors in Escherichia coli and Salmonella typhimurium. Journal of Bacteriology 102, 363-368.

WATSON, C. E. (1967). Infectious drug resistance in Shigellae in Cape Town. South African Medical Journal 4I, 682-73I.

Witchitz, J. L. \& Chabbert, Y. A. (1972). Résistance transférable à la gentamicine. II. Transmission et liaisons du caractère de résistance. Annales de l'Institut Pasteur 122, 367-378.

Yokata, T., Kanamaru, Y., Mori, R. \& Akiba, T. (I969). Recombination between a thermosensitive kanamycin resistance factor and a non-thermosensitive drug resistance factor. Journal of Bacteriology 98, 863-873.

Yoshikawa, M., Nagashima, S. \& Matsushima, S. (I97I). Genetical distinction of R factors derived from Shigellae and Salmonellae. Japanese Journal of Microbiology 15, 425-436. 